\title{
A Sustainable Agriculture: Organic Farming: A Review
}

\author{
Gunmala Gugalia \\ Department of Botany, Sangam University, Bhilwara-311 001, Rajasthan, India.
}

Received: June 2021

Accepted: August 2021

\begin{abstract}
Agriculture is the backbone of India's economy and agriculture employs more than $70 \%$ of the country's people. With the continued use of fertilizers and their negative environmental repercussions, the farming community is becoming more aware of alternative agriculture systems, such as organic farming. Organic farming is a natural farming technique that meets society's food and nutrition demands while not diminishing natural resources. Thus, by combining organic resources with high-yielding varieties and technologies, the country was able to enhance not only its food excess, but also its environmental pollution, pesticide toxicity and agricultural production sustainability. Organic farming also feeds crops with macronutrients and micronutrients, as well as improving the physical, chemical and biological qualities of the soil. In organic farming, pest and disease management alternatives rely mainly on preventive measures rather than curative treatments, which are based on environmentally safer management strategies. The priority has been placed on maintaining the ecosystem's health, allowing plants to become resistant to insect pests and illnesses.
\end{abstract}

Key words: Environment, Insect-pest management, Organic farming, Sustainability, Yield.

Agriculture has met the basic necessities of India's rising population for the past few decades, with 67 per cent of our population and 55 percent of our entire labor force relying on it (Chandrashekar, 2010). The Green Revolution has resulted in significant advancements in agricultural technology and policy in order to increase food production in order to meet the demands of an ever-increasing global population. Although food availability and production have expanded as a result of the usage of chemical fertilizers, herbicides, insecticides and pesticides, consumers have become more quality conscious in recent years and are increasingly demanding ecologically safe, chemical-free healthful foods (Chander et al., 2011).

Organic food production is not only tough for producers in today's agricultural world, but it also opens up new export options for the products. Organic farming is a type of farming that focuses on developing crops in such a way that organic wastes and biological elements are used to keep the soil healthy. "Organic agriculture is a production system that supports the health of soils, ecosystems and people," according to IFOAM (International Federation of Organic Agriculture Movement). Rather than using harmful inputs, it relies on biological processes, biodiversity and cycles that are tailored to local conditions. Organic farming's main goal is to create a self-sustaining farming system in harmony with nature that produces ecologically and economically sustainable pure food while also enriching the surrounding biodiversity and its various components.

On an organic farm, managing the ecology is difficult. Maintaining the ecosystem's health has been prioritized, allowing plants to evolve resistant to insect-pest and disease attack. The preliminary defense against the attack of insectpests and diseases is broad ecosystem management through minor changes in cultural practices such as crop rotation and soil quality management through the addition of organic amendments, followed by the use of curative methods such as predators, parasitoids, plant products and environmentally safer chemicals. No doubt, the advantages of organic farming will outshine its disadvantages but on the practical side, it has got several constraints as it is unable to satisfy the increasing food demand and thus a challenge to the national food security, lack of knowledge, limited availability of organic fertilizers and manures, profitability to the farmers and affordability of organic produce by the consumers are some of the problems of organic farming in hand. Considering the rising demand for organic products both nationally and internationally, with proper implementation of policies encouraging organic farming their implementation and marketing there is great scope for the organic food industry to create a huge positive impact on the Indian economy (Mikhil et al, 2019).

\section{Scenario at the global level}

Organic farming's worth is slowly rising and it is currently implemented in practically every country on the planet, with its portion of land increasing by the day. According to FiBLIFOAM (World of Organic Agriculture - Statistics and Emerging Trends, 2015), there are roughly 43.1 million ha of certified organic farming area in 170 countries (up from 160 in 2010). The regions with the highest organic agricultural land area are Oceania (17.3 million hectares) and Europe (11.5 million ha). Latin America has 6.6 million

*Corresponding author's E-mail: gunmala24@gmail.com 
hectares, 3.4 million hectares in Asia, 3 million in North America and 1.2 million in Africa. The countries with the largest organic areas are Australia, the United States and Argentina. In developing countries, a quarter of all agricultural land, as well as almost $80 \%$ of organic agriculture output and markets, are found. In Asia, Europe, Oceania and North America, the amount of land devoted to organic farming has risen dramatically in recent years. In terms of raw plant products, both the USDA and the Euro Zone have recognized NPOP rules of certification and production as similar to theirs (Kumar, 2019).

\section{India's Current Status of Organic Farming}

In India, organic farming has been practiced since ancient times. The magnificent Indian civilization thrived on organic farming and grew to be one of the world's wealthiest nations (Deshmukh and Babar, 2015). Crop production in organic farming is dependent on intrinsic biological processes in combination with the usage of organic waste, such as crop, livestock and farm waste. Organic standards require that organic lands be managed for three years before the first certified organic crop is harvested using organic methods. Because both the soil and the management are adapting to the new system, this is known as the adjustment phase. Even insects, rodents and weeds adapt over this period. As a result, organic farming appears to be a viable option for long-term sustainability.

With roughly 1,49 million hectares of organic land and roughly 1,70 million MT (2015-16) of certified organic products, India is a leading organic production country (World of Organic Agriculture - Figures and Emerging Trends, 2018). According to available data, India ranked ninth in the world in terms of organic agricultural acreage and first in terms of producers in 2018. (FIBL and IFOAM Year Book 2018). With an 11th-place world ranking in export pricing, India is also a significant exporter of organic commodities. A National Organic Production Program has also been developed by the Indian government (NPOP). This program aims to accredit, promote and establish organic agriculture standards throughout the country.

According to the findings of a survey (Organic Agriculture World-Statistics and Emerging Trends, 2018). In India, there are around 1.78 million hectares of organic agricultural. India has generated roughly 1.70 million MT of certified organic products, which include oil seeds, sugar cane, cereals and millets, cotton, pulses, medicinal plants, tea, fruits, spices, dried fruits, vegetables, coffee and other food kinds. Producing organic cotton yarn, functional food products and other items is not restricted to the edible sector. Madhya Pradesh, Maharashtra, Karnataka, Uttar Pradesh and Rajasthan are the top producers of various states.

Plant compounds or extracts have been discovered to be effective against a wide variety of infections, in addition to standard fungicides and microbial bio-control agents (Amadioha 2003).

\section{Organic agriculture conviction}

\section{Principle of health}

Organic agriculture should sustain and improve the health of the land, plant, animal, human and planet.

\section{Sustainable principle}

It should be built on living ecological systems and a cycle and it should work with, follow and assist in the maintenance of these systems.

\section{Equity principle}

Organic agriculture should be based on equitable interactions with the shared environment and life opportunities.

\section{Principle of safety}

It should be managed in a safe and responsible manner to protect current and future generations' health and well-being, as well as the environment.

\section{India's patrons of organic food}

Organic food consumption in India is increasing. With more than 66 percent of parents preferring organic food, the most compelling reason to buy organic food was concern for their children's health. Despite the fact that organic food costs more than $25 \%$ more than conventional food in India, many parents are ready to pay the greater price because of the health benefits they believe organic food provides. Importing countries accept Indian organic products that have been duly certified by recognized Indian certifying authorities.

The overall amount of exports in 2017-18 was 4.58 lakh metric tons (MT). Organic food exports accounted for roughly INR 3453.48 crore in revenue. Organic products are exported to the United States, the European Union, Canada, Switzerland, Australia, Israel, South Korea, Vietnam, New Zealand and Japan, among other destinations. Oil Seeds (47\%) are exported with Cereals and Millets (10\%), Plantation Crop Items like Tea and Coffee (8.96\%), Dry Fruits (8.88\%), Spices and Condiments (7.76\%) and other products.

\section{Organic farming strategies for insect-pest and disease management}

Under the heading of organic farming, pest and disease control measures, insect pests and illnesses were divided into the following categories.

1. Crop rotation, soil health control and the use of insect-resistant plants are all examples of changes in cultural practices.

2. Management operations such as giving hedge rows and protective belts to reintroduce natural enemies.

3. Inoculation, inundation, or release of biological control agents such as insect pests, parasitoids, or insect diseases.

4. The use of botanical ingredients and mixes as healing measures, such as Panchagavya, Dasagavya and mineral oils.

5. Use of pheromones and other enticing substances.

6. Use of certified organic pesticides and other pesticides. 


\section{Changes in cultural practices}

Many of the preventive procedures utilized in modern and organic farming today have their beginnings in traditional farming. Cultural methods are among the oldest pest management approaches. A small change in cultural behaviours will have an impact on the environment as a whole. Corn earworm is less of an issue in early-planted sweet corn. Off-season growing of cauliflower and cod, especially in endemic areas, should be avoided (Shivalingaswamy and Satpathy, 2007). When brinjal was treated with various organic manures, Godase and Patel (2002) reported a much lower whitefly population. According to Mahto and Yadav (2003), stem fly infestation in vegetable pea plants grown on vermic compost from diverse organic sources was reduced when sprayed in combination with DAP. When neem cake was treated at $1.7 \mathrm{t} / \mathrm{ha}$, Godse and Patel (2003) found that it had the lowest (14.3 per cent) brinjal shoot and fruit borer infestation, but nitrogen fertilizer levels were higher.

\section{Natural enemy restoration conservation practices}

Varghese (2003) discovered that diverse organics and botanicals were proven to be highly beneficial for coccinellids and predatory mites and that they were equivalent to untreated care. Kumar (2004) investigated the effects of indigenous plant products and cow urine on natural enemies in the chilli environment. Coccinellids and Chrysoperla spp. have been found to be beneficial to all of the indigenous sprays mentioned in the research. With the exception of $3 \%$ garlic chilli kerosene. Improvements to organic soil, such as vermicompost, neem cake and botanical sprays like NSKE and neemazal, have been found to be particularly beneficial to the natural enemy fauna in the chili environment, according to Soumya (2007). The organically manured treatments like farmyard manure, neem cake, vermicompost recorded lowest pest population compared to straight fertilized treatments. The groundnut plants that received organic manures recorded low nitrogen, higher levels of phenols and tannins whereas the straight fertilized groundnut leaves recorded the vice versa. The pest incidence was correlated with nitrogen content and negatively correlated with phenols and tannins. The organic manures induced the phenols and tannins production in groundnut plant and thus the induced resistance plays an important role in groundnut insect pest management (Roa, 2003).

\section{Pesticides, both organic and non-organic}

Kaolin is a clay that forms naturally when aluminum minerals, such as feldspar, weather with kaolinite as its major component. Kaolin is pulverized to a consistent particle size for use as a plant protectant that is applied as a water suspension to specific plant regions. This chemical has been shown to be efficient against insects as well as illnesses. Kaolin stops insects by leaving a white layer on the leaves, making the covered plant unattractive to them. The white film could make it difficult to locate the insect's host. This also acts as a physical barrier to keep insects out of sensitive areas and as a repellant by creating an inappropriate food or egg-laying surface (Haldhar et al., 2017).

\section{Limitations for plant protection through an organic approach}

1. Plant protection in organic farming is hampered by high costs of organic pesticide inputs, a lack of a market for organic pesticides, a lack of organic pesticide inputs and lower yield.

2. Natural pesticides are typically less durable than synthetic pesticides and decay quickly in the environment, resulting in lower activity and shorter residual periods than synthetic alternatives.

3. Lack of understanding, low employment possibilities and lack of organic pesticide experience are the other significant restrictions.

\section{Thrusts for future research}

1. Develop weather-based forecasting modules for major crop insects, pests and diseases.

2. Insect pests and diseases are surveyed and controlled.

3. Identification of sources of resistance to key insect pests and agricultural diseases

4. Evaluation of plants, microorganisms and bioagents for insecticidal activity against crop pests.

5. Development of plague-control modules for essential crops.

6. Determination of environmentally dependent economic threshold values for the principal pests under agro-climate settings.

7. Insecticide, fungicide and pesticide resistance in plant insects and pathogens are monitored and managed.

\section{CONCLUSION}

In the current circumstances, the Green Revolution is confronted with significant environmental issues, including environmental deterioration and depletion of all natural resources, including air, water, soil, forests, biodiversity and so on. Organic farming is the only viable and successful solution to these significant concerns. For any given crop, location, manpower and capital availability conditions, there are theoretically numerous ideal crop security solutions accessible. Timing, integrated pest control, organic, natural, biodynamic and biological crop production and security systems are only a few examples.

Alternative strategies may employ fundamentally different conceptual approaches, yet can also serve as viable collections of best crop production management techniques. Alternative research, pricing support, agricultural policies and land-use practices may be required to promote and develop alternative crop protection strategies that are commercially, socially and environmentally viable. In order to increase crop safety in organic farming, researchers will focus on identifying and gaining access to a set of crop production materials and methods that work together as a favored growth syndrome. 


\section{REFERANCES}

Amadioha, A.C. (2003). Evaluation of some plant leaf extracts against Colletotrichum lindemuthianum in cowpea. ActaPhytopathologica Entomologica-Hungarica. 38: 259-265.

Chander, M., Subrahmanyeswari, B., Mukherjee, R., Kumar, S. (2011). Organic livestock production: An emerging opportunity with new challenges for producers in tropical countries. Scientific and Technical Review of the Office International des Epizootices. 30(3): 969-983.

Chandrashekar, H.M. (2010). Changing scenario of organic farming in India: An overview. International NGO Journal. 5(1): 34-39.

Deshmukh, M.S. and Babar, N. (2015). Present Status and Prospects of Organic Farming in India. European Academic Research. 3(4): 20-28.

FIBL (World of Organic Agriculture - Statistics and Emerging Trends, 2018).

Godase, S.K. and Patel, C.B. (2002). Studies on the influence of organic manures and fertilizerdoses on the intensity of sucking pests infesting brinjal. Plant Protection Bulletion. 54(2): 3-6.

Godase, S.K. and Patel, C.B. (2003). Effect of different treatments of organic manures and fertilizers on infestation of brinjal shoot and fruit borer. Pestology. 27(5): 9-12.

Haldhar, S.M., Jat, G.C., Deshwal, H.L., Gora, J.S. and Singh, D. (2017). Insect Pest and Disease Management in Organic Farming. Research Gate. 359-390.

http://apeda.gov.in/apedawebsite/organic/Organic_Products.htm. Kumar (2004). Evaluation of organics and indigenous products for the management of Helicoverpa armigera in chilli. M.Sc. (Agri.) Thesis, University of Agricultural Sciences, Dharwad, India.
Kumar, M.S., Reddy, G.C. and Sangwan, P.S. (2017). A review on organic farming - sustainable agriculture development. International Journal of Pure and Applied Bioscience. 5(4): 1277-1282.

Mahto, T.P. and Yadav, R.P. (2003). Effect of vermicompost prepared from different organic sources alone or in combination with chemical fertilizer on stem fly incidence and yield parameters in vegetable pea Rajasthan University of Agriculture. Journal of Research. 13(1 and 2): 26-29.

Mikhil, M., Kumar, V. and Bisarya, D. (2019). Organic farming in present agriculture scenario. Journal of Emerging Technologies and Innovative Research. 6(1): 9-11.

Rao, K.R. (2003). Influence of host plant nutrition in the incidence of Spodoptera litura and Helicoverpa armigera on groundnut. Indian Journal of Entomology. 65(3): 386-392.

Shivalingaswamy, T.M. and Satpathy, S. (2007). Integrated Pest Management in Vegetable Crops. In: Entomology: Novel Approaches, [(Eds) Jain, P.C. and Bhargava, M.C.], New India Publishing Agency, New Delhi, pp. 353-75.

Soumya, G. (2007). Role of vermicompost, vermiwash and other organics in the management of thrips and mites of chilli. M. Sc. (Agri.) Thesis, University of Agricultural Sciences, Dharwad, India.

Varghese, T.S. (2003). Management of thrips, Scirtothrips dorsalis Hood and mite, Polyphagotarsonemus latus Banks on chilli using biorationals. M.Sc. (Agri.) Thesis, University of Agricultural Sciences, Dharwad, India. 